\section{Wechselwirkung, hydrophobe}

\section{H. Fiedler}

Erfurt, Deutschland

Englischer Begriff hydrophobic interaction; hydrophobic effects

Definition Hydrophobe Wechselwirkungen zwischen apolaren Seitengruppen stabilisieren die Struktur der Proteine und Nukleinsäuren durch Ausschluss von Wassermolekülen. Hydrophobe Effekte sind auch an der Bildung von Zellmembranen und Vesikeln und an Wechselwirkungen von Proteinen mit kleinen Molekülen beteiligt.

Beschreibung Eine ungefaltete Polypeptidkette versucht, eine Konformation einzunehmen, bei der ihre hydrophoben
Aminosäuren (Ala, Val, Leu, Ile, Phe, Met) im Inneren des Moleküls vor Wasser geschützt sind, während die umgebenden Wassermoleküle ihr Netzwerk beibehalten und mit den polaren Seitenketten der Aminosäuren interagieren (hohe Entropie). Lagern sich apolare Gruppen aneinander, so wird ihre Kontaktfläche mit Wasser verringert und die freie Energie herabgesetzt. Es handelt sich um relativ schwache Bindungskräfte, die aber in ihrer Vielzahl wesentlich zur Stabilität der Protein- und DNA-Struktur beitragen.

Chaotrope Substanzen, wie Ethanol, stören das Wasserstoffbrückennetzwerk des Wassers und vermindern hydrophobe Effekte, Wasserstoffbrückenbindungen, Van-derWaals-Kräfte und die Hydratationshülle. Dadurch werden die nativen Strukturen von Proteinen, DNA und Zellmembranen destabilisiert oder sogar denaturiert. Chaotrope Salze, die in Lösung dissoziieren, verhindern oder schwächen besonders die Ionenbindungen, 